$10-1-1988$

\title{
Judicial Activism, Economic Theory and the Role of Summary Judgment in Sherman Act Conspiracy Cases: The Illogic of Matsushita
}

\author{
James F. Ponsoldt \\ University of Georgia School of Law, ponsoldt@uga.edu \\ Marc J. Lewyn \\ University of Georgia School of Law
}

Prepress SSRN

\section{Repository Citation}

James F. Ponsoldt and Marc J. Lewyn, Judicial Activism, Economic Theory and the Role of Summary Judgment in Sherman Act Conspiracy Cases: The Illogic of Matsushita (1988),

Available at: https://digitalcommons.law.uga.edu/fac_artchop/527

This Article is brought to you for free and open access by the Faculty Scholarship at Digital Commons @ University of Georgia School of Law. It has been accepted for inclusion in Scholarly Works by an authorized administrator of Digital Commons @ University of Georgia School of Law. Please share how you have benefited from this access For more information, please contact tstriepe@uga.edu. 


\section{Judicial activism, economic theory and the role of summary judgment in Sherman Act conspiracy cases: the illogic of Matsushita}

BY JAMES F. PONSOLDT* AND MARC J. LEWYN**

The proper role of neoclassical economic theory in the resolution of antitrust disputes will continue to be debated into the next administration. ${ }^{1}$ The Reagan Administration has succeeded in persuading the Supreme Court to incorporate laissez-faire

* Professor of Law, University of Georgia School of Law, J.D., Harvard University, 1972.

** Member of the District of Columbia Bar. J.D., University of Georgia, 1986.

AUTHORS' NOTE: The authors acknowledge the significant assistance in the preparation of this article of Michael Youtt, a member of the 1989 class of the University of Georgia School of Law.

1 The existence and contents of this two volume symposium are evidence of the continuing debate. See, e.g., Ponsoldt, "Introduction," 33 The Antitrust Bulletin 201 (1988). 
assumptions and goals into Sherman and Clayton Antitrust Acts ${ }^{2}$ jurisprudence in at least three major decisions, ${ }^{3}$ although the long-range importance of the holdings in two of those cases remains somewhat in doubt. ${ }^{4}$

One of those decisions, however, reflects more than just a disagreement about applications of the antitrust laws. In Matsushita, supra, the Court, ordering summary judgment for defendants at the urging of the Justice Department, has tampered with fundamental "right-to-jury" principles $s^{5}$ and, in preferring eco-

226 Stat. 209 (1890), codified as amended, 15 U.S.C. $\S \S 1-7$ (1987); 38 Stat. 730 (1914), codified as amended, 15 U.S.C. $\$ \S 12-27$ (1987).

3 Matsushita Electric Industrial Co. v. Zenith Radio Corp., 475 U.S. 574 (1986); Cargill v. Montfort, 107 S. Ct. 484 (1986); Business Electronics Corp. v. Sharp Electronics Corp., 108 S. Ct. 1515 (1988).

4 Both Cargill, supra, and Business Electronics, supra, reflect obvious compromises between competing views, in which the Court went out of its way to purport to rely upon existing precedent. Cargill merely applied the Court's holding in Brunswick Corp. v. Pueblo BowlO-Mat, 429 U.S. 477 (1977), to require that private plaintiffs show antitrust injury in equity suits as well as damage actions. The Court rejected the more extreme view of the Justice Department that a private competitor never should be allowed antitrust standing to challenge a merger. The growing involvement of the states, and possibly of consumer classes, in challenging mergers, should reduce the impact of Cargill.

The Court in Business Electronics expressly reaffirmed as modes of analysis the per se rule for vertical price-fixing and the market-based rule of reason for vertical non-price restraints. It remains to be seen whether the Court will allow the plaintiff in a distributor termination case, where the motive for the termination is to impede retail price competition, as in Business Electronics, to succeed in proving "unreasonableness" by showing anticompetitive motive, without proving that defendants possess a high market share. See generally, Flynn, "The 'Is' and 'Ought' of Vertical Restraints After Monsanto," 71 CORNell LAW REVIEW 1095 (1986).

5 It has been held that, even in an equity case in which the Seventh Amendment jury right would not apply, a counterclaim for damages triggers the right to a jury trial on common issues, Beacon Theatres $v$. Westover, 359 U.S. 500 (1959). See also, for a discussion of the right to a jury even in complex antitrust cases, U.S. Financial Securities Litigation, 609 F.2d 411 (9th Cir. 1979). 
nomic illusion to the reality of a pretrial record, has revealed itself as capable of uncommon judicial activism. Briefly, the decision in Matsushita (i) ignores existing Sherman Act summary judgment precedent; ${ }^{6}$ (ii) undermines longstanding rules of construction applicable in all summary judgment cases, thereby judicially amending the language of Rule 56, F.R. Civ. P., itself;" (iii) substitutes the deductive assumptions of neoclassical economic theory for record evidence, standing logic on its head; ${ }^{8}$ (iv) misapplies predatory pricing theory in the context of a conspiracy case; ${ }^{9}$ and (v) creates a standard for proof of a conspiracy in civil Sherman Act cases which is far greater than the standard of proof

6 See, discussion at nn. 63-72 and accompanying text.

7 See, discussion at nn. 59-62 and accompanying text.

8 In holding that since rational businessmen would not engage in long-term predatory pricing, according to economic theory (because they would never be able to recoup their losses in hypothesized competitive markets), they therefore did not do so in combination, the Court ignored uncontradicted record evidence that defendants did engage in long-term, parallel low or below cost pricing in the United States. Obviously, the economic theory relied upon by the Court failed to factor in the possibility of an additional motive: full employment for Japanese workers, subsidized by Japanese consumers and the Japanese government, which results from defendants' penetration of the American market. As an anecdotal aside, the reasoning of the Court in Matsushita (although not the result) is the target of private hilarity among Japanese lawyers and economists.

9 Assuming that the Court and the economic theorists it relied upon were correct that no rational businessman would engage in unilateral long-term predatory pricing because such pricing conduct would be against his economic self-interest, such an "against economic selfinterest" characterization constitutes solid evidence that defendants did act in concert when engaging in consciously parallel pricing conduct, as will be discussed below. In other words, the Court applied its economic theory to reach a conclusion directly contrary to the correct one. Longstanding conspiracy law teaches that if two or more persons consciously are engaging in complementary or parallel conduct which neither one would engage in independently, they likely are acting pursuant to a mutual understanding - a conspiracy. See, discussion at nn. 116-126 and accompanying text. 
for conspiracies in criminal cases, including criminal Sherman Act cases. ${ }^{10}$

The primary concern of this article is the last noted effect of the Matsushita decision. By advocating and adopting the Matsushita standard for civil Sherman Act conspiracies, and maintaining a more liberal standard for proof of criminal conspiracies, the Justice Department and a majority of the Court, respectively, have stepped into the overtly political arena and implicitly disavowed fundamental tenets of our legal system." The schizophrenic attitude toward proof of Sherman Act conspiracies reflects the administration's underlying inconsistency between "laissez-faire" and "tough on crime"; the Administration fails to recognize that criminal antitrust enforcement is as interventionist as is civil enforcement of the same statutes.

This article will briefly discuss administration antitrust enforcement policy, through reference to speeches and policy statements. It will then describe the Matsushita decision and traditional antitrust summary judgment standards. The article will review and compare existing criminal conspiracy standards and their development and application in criminal antitrust cases. Finally, it will take a closer look at the proper relationship between economic principles and the conspiracy standard when proof of conspiracy must be inferred from circumstantial evidence of parallel business conduct.

10 See, discussion at nn. 82-112 and accompanying text.

11 That the "beyond a reasonable doubt" standard for proof of elements of a criminal offense, incorporated in the due process clause, is stricter than the "preponderance of the evidence" test for proof of elements of a civil action should not require citation or elaboration. The Matsushita standard for proof of the existence of a conspiracy in a civil action has been expressly disavowed as too strict by the courts in criminal cases, as will be discussed below, yet the Matsushita standard must be satisfied by a civil action plaintiff at the summary judgment stage. At best, Matsushita creates major incentives for discovery abuses by antitrust defendants, including perjury and document destruction. At worst, Matsushita represents a retreat from basic democratic principles embodied in the Seventh Amendment. 


\section{Background}

During the Reagan Administration's tenure, an interesting dichotomy has developed regarding federal antitrust policy. On the one hand, the administration, through its enforcement agencies-the Department of Justice and the Federal Trade Commission-advocates strict enforcement of criminal antitrust law, while on the other hand, it declines to seek, and even opposes, civil liability for corporations which implement activities restraining commerce. The cause of this inconsistency is the Reaganites' desire to stop a perceived escalation of "criminality" coupled with an unwavering, if not illogical, dedication to laissezfaire economics and a noninterventionist "regulatory" policy, even with respect to substantially the same kind of underlying business conduct.

Although identified with the Chicago school antitrust approach, ${ }^{12}$ the Reagan Administration's "get tough" policy towards criminal antitrust enforcement distinguishes it. ${ }^{13}$ Several characteristics of the Justice Department's recent activities highlight this increased emphasis on criminal enforcement. First, the three most recent Antitrust Division leaders, Paul McGrath, Douglas Ginsburg, and Charles Rule, ${ }^{14}$ have consistently identi-

12 When referred to throughout this article, the term, "Chicago school," should be construed in its broadest sense to refer to the wellknown legal analysis which stresses efficiency-based rationales. Probably the seminal and assuredly the most influential study of Chicago school reasoning applied in the area of antitrust law is Judge Robert Bork's work, The Antitrust Paradox. Also, the academic writings and judicial opinions of Judge Richard Posner provide clear examples of the application of Chicago-school theories. See, e.g., Posner, The Chicago School of Antitrust Analysis, 127 U. PA. L. REv. 925 (1979).

13 The Antitrust Division of the Department of Justice is responsible for the majority of the Reagan Administration's antitrust law proposals. Citations to the specific statutory proposals that embody the administration's philosophy will occur throughout the article.

14 Each of these three men has served as Assistant Attorney General of the Department of Justice, Antitrust Division. McGrath served from 1982 to 1987, Ginsburg from 1984 to 1987 and Rule's tenure began in 1986. $\mathrm{He}$ is still the Division head. 
fied tough criminal enforcement as the top priority of the Division. ${ }^{\text {is }}$ Second, recent statistics provide evidence of the declared "get tough" rhetoric. The Justice Department currently has more than 140 grand juries empaneled solely to investigate antitrust violations ${ }^{16}$ and the Department has initiated "three times the number of criminal cases" as the Carter Administration. ${ }^{17}$ This increase has resulted in "two and one-half times the number of fines" and an increase in the frequency and length of jail sentences. ${ }^{18}$ The primary areas of emphasis continue to be bidrigging and horizontal price fixing. ${ }^{19}$

Third, the Department has submitted legislative proposals which, if enacted, would increase federal enforcement activity in the criminal antitrust area. ${ }^{20}$ These proposals request, among other things, treble damages for criminal convictions rather than the current remedy of actual costs and the mandatory imposition of jail sentences as opposed to mere fines for corporate officials found guilty of collusive practices. ${ }^{21}$

15 See M. Crane, D. Foster, C. Hills, R. Pogue, "Interview with J. Paul McGrath, Assistant Attorney General, Antitrust Division," 53 AntrTrust L.J. 27, 31 (1984); J. Halverson, J. Loftis, H. Reasoner, T. Briggs, "60 Minutes with Douglas H. Ginsburg, Assistant Attorney General, Antitrust Division," 55 AntrTrust L.J. 255, 260 (1986); T. Briggs, "60 Minutes with Charles Rule, Assistant Attorney General, Antitrust Division," 56 Antitrust L.J. 261, 264-65 (1987). (Referred to hereinafter as "60 Minutes with Charles Rule.")

16 Briggs, supra, note 15 at 265.

17 Id.

$18 I d$.

19 Id. Rule notes that the five areas that currently account for the highest percentage of grand jury investigations are road building, electrical contracting, utility contracting, movie-split cases and moving and storage.

20 See, e.g., Antitrust Remedies Improvement Act, S. 2162 and H.R. 4250, 99th Cong., 2d Sess. (1986).

21 Id. 
On the other hand, the Department has increased its amicus curiae brief program and now submits briefs regarding civil antitrust cases to the Supreme Court even when not requested to do so. In these briefs the Department frequently urges increased flexibility and deference to neoclassical economics in the Court's execution of antitrust law. Consequently, the Department since 1981 has supported the defendant in the majority of these actions. ${ }^{22}$

The deemphasizing of civil antitrust enforcement has occurred concomitantly with the "get tough" approach. Efficiency-based principles underlie the Justice Department's Merger Guidelines ${ }^{23}$ and Guidelines for Vertical Restraints. ${ }^{24}$ Moreover, decreased budget requests, employment cutbacks and a drastic reduction in the number of civil cases initiated, especially in the area of merger control, reveal a firm commitment to the laissez-faire approach in the civil antitrust area. Furthermore, the Department has proposed extensive legislation designed to reduce antitrust enforcement in the private arena. ${ }^{25}$ The obvious cause of this

22 For a list of the recent Supreme Court antitrust cases in which the Department has filed an amicus curiae brief favoring the defendant, see Campbell, "The Antitrust Record of the First Reagan Administration," 64 Tex. L. REv. 353 (1985). See also, Cargill and Matsushita, supra, n. 3.

231982 Justice Department Merger Guidelines, 47 Fed. Reg. 28,493, revised, 1984 Justice Department Merger Guidelines, 49 Fed. Reg. 26,823 (June 29, 1984); reprinted in 2 CCH Trade Reg. $94490 ; 46$ BNA ATRR 1126 (June 14, 1984).

2450 Fed. Reg. 6263 (Feb. 14, 1985); reprinted in CCH Trade Reg. Rep. \#687 Part II (January 30, 1985); 48 BNA ATRR 193 \& Special Suppl. \#1199 (January 24, 1985): For a record of the House Judiciary Committee's response to the Vertical Guidelines proposal, see 48 BNA ATRR 1006 (June 13, 1985).

25 Merger Modernization Act of 1986, S. 2160 and H.R. 4247, 99th Cong., 2d Sess. (1986); Interlocking Directorate Act of 1986, S. 2163 and H.R. 4248, 99th Cong., 2d Sess. (1986); Foreign Trade Antitrust Improvements Act of 1986, S. 2164 and H.R. 4249, 99th Cong., 2d Sess. (1986); Promoting Competition in Distressed Industries Act, S. 2161 and H.R. 4251, 99th Cong., 2d Sess. (1986). 
noninterventionist approach to civil actions is the administration's dedication to the efficiency-based antitrust rationale of the Chicago school.

A perfect illustration of the Antitrust Division's divergent policies concerning criminal and civil enforcement is the Antitrust Remedies Improvement Act, ${ }^{26}$ a bill proposed to Congress by the Justice Department. In this legislative proposal, the Division requests the trebling of damages when the United States seeks antitrust sanctions, but asks for a reduction in damage awards in civil actions involving private parties. ${ }^{27}$ Thus, the effect sought is to increase the deterrent of the legislation for one type of illegal act while decreasing it for another type of anticompetitive activity and, more important, to elevate the importance of the government's interpretation of the law.

The result of this schizophrenic approach to antitrust execution is the restriction of the anticompetitive activity of small bidriggers and road construction companies (the object of the majority of criminal actions) which has relatively little impact on the aggregate competitive nature of the market contrasted with authorization and even encouragement of major public anticompetitive activities which have far-reaching economic effects. Furthermore, the Department's conscious decision not to intervene to help prosecute activity which arguably violates the Clayton and Sherman Acts coupled with its prodefendant amicus curiae brief program raises strong questions as to the constitutional limits of prosecutorial discretion-can the executive branch refuse to enforce legislatively adopted provisions simply because it believes that doing so will cause inefficiency? ${ }^{28}$ The Department's successful amicus filing in Matsushita is representative of the outcome when ideology overwhelms commitment to law.

26 S. 2162 and H.R. 4250, 99th Cong., 2d Sess. (1986).

27 Id.

28 Scalia, "The Role of the Judiciary in Deregulation," 55 AntrTRUST L.R. 191 (1986). (Justice Scalia briefly reviews the history of executive agency inaction from Marbury v. Madison to the present. He gives great weight to prosecutorial discretion.) 


\section{The Matsushita decision}

Matsushita involved an alleged conspiracy among twenty-one corporations that manufactured or sold television receivers and other consumer electronic products. ${ }^{29}$ Plaintiffs, two American television manufacturers, contended that defendants conspired to suppress competition by fixing high prices for television sets sold in Japan and using the proceeds to fund a conspiracy in the United States to charge artificially low prices in order to penetrate and maintain a significant share of the American market. ${ }^{30}$ Plaintiffs alleged that these actions violated, inter alia, Section One of the Sherman Act and the Antidumping Act of 1916."

29 Defendants were Japanese firms and their Japanese and American subsidiaries. Japanese parent corporations named as defendants included Matsushita Electric Industrial Corp., Ltd., Mitsubishi Corporation, Toshiba Corporation, Hitachi Ltd., Sharp Corporation, Sanyo Electric Company Ltd. and Mitsubishi Electric Corporation. In re Japanese Electronic Products Antitrust Litigation, 723 F.2d 238, 251 (3d Cir. 1983). Defendant subsidiaries included Mitsubishi International Corp., Matsushita Electronics Corp. of America, Matsushita Electric Corp., Matsushita Electric Trading Corp., Quasar Electronics Corp., Toshiba American Inc., Hitachi Sales Corp. of Japan, Hitachi Sales Corp. of America, Sharp Electronics Corporation, Sanyo Electric, Inc., Sanyo Electric Trading Co., Sanyo Electric Manufacturing Co., Sony Corp. of America, and Melco Sales Inc. 723 F.2d at 251, n. 4. Sony Corporation and its sales subsidiary, Sony Corporation of America were originally named as defendants but settled nine years before the litigation reached the Supreme Court. 723 F.2d at 251, n. 3.

30106 S. Ct. $1348,1354-55$ (1986).

31 Id. at 1351-1352. The Antidumping Act of 1916, 15 U.S.C. $\$ 72$ (1982) generally prohibits "price discrimination between purchasers in different national markets." J. VINER, DUMPING: A ProBLEM IN INTERNATIONAL TRADE 4 (1966). The Act's text provides in relevant part:

It shall be unlawful for any person importing or assisting in importing any articles from any foreign country into the United States, commonly and systematically to import, sell or cause to be imported or sold such articles within the United States at a 
In support of their allegations, plaintiffs presented a multitude of evidence at trial, culled from years of discovery..$^{32}$ After

price substantially less than the actual market value or wholesale price of such articles, at the time of exportation into the United States, in the principal markets of country of their production, or of other foreign countries to which they are commonly exported after adding to such market value or wholesale price, freight, duty and other charges or expenses necessarily incident to the importation and sale thereof in the United States; Provided, that such acts or acts be done with the intent of destroying or injuring an industry in the United States, or of preventing the establishment of an industry in the United States, or of restraining or monopolizing any part of trade or commerce in such articles in the United States.

32 Pursuant to the trial court's pretrial order, plaintiffs filed 250,000 documents evidencing the alleged conspiracy. Plaintiffs' documentation included the following:

(1) various agreements and rules of certain Japanese manufacturer's associations relating to export practices;

(2) diaries of officials of several of the Japanese defendants, alleged to contain evidence of the conspiracies referenced in plaintiffs' complaint;

(3) export control agreements entered into by Japanese manufacturers;

(4) the rules of the Japanese Machinery Exporters Association (JMEA) which implemented the export control agreements and included provisions allocating the U.S. market by restricting each manufacturer to five customers and requiring the registration of trademarks. The rules also contained the "rationales" of the agreements, explaining the necessity of stabilizing the export trade;

(5) the findings of the U.S. government, including the dumping findings by the Treasury Department and the finding by the International Trade Commission of injury sustained by U.S. manufacturers of television receivers;

(6) evidence of similar conduct of defendants in selling consumer electronic products in the U.S. at prices substantially lower than those at which the same merchandise is sold in Japan, and at below cost;

(Footnote continued on following page) 
ruling the majority of the evidence inadmissible, ${ }^{33}$ the trial court considered the defendants' motion for summary judgment in light of the newly eviscerated record. ${ }^{34}$ The Court found that the evidence of defendants' joint action raised no genuine issue of material fact as to the existence of a conspiracy. ${ }^{35}$ The trial court granted summary judgment to defendants.

The Court of Appeals for the Third Circuit reversed, in great part because the appellate court found that much of the evidence

(Footnote continued from previous page)

(7) evidence indicating that the Japanese defendants' U.S. subsidiaries similarly and consistently operated at a loss, as reported in their tax returns and financial statements;

(8) the opinion of plaintiffs' experts that defendants constituted a cartel and engaged in both the home market and export facets of the alleged conspiracy.

Zenith Radio Corp. v. Matsushita Elec. Indus. Co., 513 F. Supp. 1100, 1126-1127 (1981).

33 In three separate opinions, the District Court issued pretrial orders excluding various categories of evidence. In the first of these, the court characterized a variety of U.S. and Japanese government documents as hearsay, irrelevant and unfairly prejudicial. Zenith Radio Corp. v. Matsushita Elec. Indus. Co., 505 F. Supp. 1125 (E.D. Pa. 1980)

The second opinion held inadmissible the diaries of Japanese officials, internal memoranda of certain defendants and minutes of Japanese export council meetings. Zenith Radio Corp. v. Matsushita Elec. Indus. Co., 505 F. Supp. 1190 (E.D. Pa. 1980).

The final opinion considered the admissibility of testimony from five of plaintiff's expert witnesses. The experts' testimony took the form of lengthy reports discussing a range of economic, financial and technological issues relating to the alleged conspiracy. The court found that the experts relied on untrustworthy sources, and that they acted not as economists, but as "conspiracyologists engaged in inadmissible "oathhelping.' " Zenith Radio Corp. v. Matsushita Elec. Indus. Co., 513 F. Supp. 1100, 1137-1138 (E.D. Pa. 1981).

34 As the district court noted, the evidentiary rulings not only "narrowed markedly the scope of the viable record . . . , but [also] virtually emasculated plaintiff's case." Zenith Radio Corp. v. Matsushita Elec. Indus. Co., 513 F. Supp. 1100, 1139 (E.D. Pa. 1981).

35513 F. Supp. 1100, 1180-1318 (E.D. Pa. 1981). 
excluded at trial was in fact admissible. ${ }^{36}$ Reviewing an expanded record, the court discovered direct evidence of some concerted action. ${ }^{37}$ The presence of direct evidence, the court noted, tended to demonstrate the existence of an illegal conspiracy "without the intervention of the proof of any other fact." ${ }^{38}$ The appellate panel also found significant circumstantial evidence of a conspiracy. ${ }^{39}$ The cumulative effect of the direct and circumstantial evidence, the court noted, ${ }^{40}$ would allow a reasonable factfinder to infer an agreement between defendants to stabilize prices in the Japanese market, thereby deriving profits from which a conspiracy to fix low prices in the United States could be funded. ${ }^{41}$

In a 5-4 decision authored by Justice Powell, the Supreme Court reinstated the trial court's judgment. ${ }^{42}$ The Court began its analysis of defendants' summary judgment motion by noting the general rule that a genuine issue of material fact must exist to present a case to the jury. ${ }^{43}$ The Court stated that defendants, with their own sworn denials, had carried their initial burden of demonstrating the absence of a material dispute, shifting the burden of presenting a genuine issue for trial to the plaintiffs. ${ }^{44}$ In

36 In re Japanese Electronic Products Antitrust Litigation, 723 F.2d 238, 260-303 (3d Cir. 1985).

37 Id. at 304.

38 Id. at 304.

39 Id. at 304-319.

40 Id. at 304-305.

41 Id. at 304-319.

42 Matsushita Electric Indus. Co., Ltd. v. Zenith Radio Corp., 106 S. Ct. 1348 (1986).

43 Id. at $1355-56$.

44 Id., defendants cited Rule 56(e) of the Federal Rules of Civil Procedure which provide in pertinent part:

(Footnote continued on following page) 
considering whether plaintiffs had satisfied this requirement, the court surprisingly held that if the context of plaintiffs' claim renders the contention economically implausible, regardless of record evidence, then summary disposition is appropriate. ${ }^{45}$ The Court, quoting Monsanto v. Spray Rite Corp. ${ }^{45}$ further concluded that economic theory suggesting that the alleged concerted action made no economic sense, undermining the possibility that a conspiracy existed. ${ }^{47}$

\section{(Footnote continued from previous page)}

When a Motion for Summary Judgment is made and supported as provided for in this rule, an adverse party may not rest upon the mere allegations or denials of his pleadings, but his response, by affidavits or as otherwise provided in this rule, must set forth specific facts showing that there is a genuine issue for trial. If he does not so respond, summary judgment, if appropriate, shall be entered against him.

Fed. Rule Civ. Proc. 56(e).

45 Matsushita Electric Indus. Co. v. Zenith Radio Corp., $106 \mathrm{~S}$. Ct. 1348-1356 (1986). ". . . . . If the claim is one that simply makes no economic sense-respondents must come forward with more persuasive evidence to support their claim than would otherwise be necessary." $106 \mathrm{~S}$. Ct. at 1356.

\section{U.S. 752 (1984).}

47 Matsushita, $106 \mathrm{~S}$. Ct. at 1357 (quoting Monsanto, 465 U.S. at 764 (1984)). Monsanto involved a manufacturer's termination of a discount distributor after the distributor's competitors had complained to the manufacturer about the distributor's price cutting. The terminated discount distributor, Spray Rite, produced evidence at trial that it had been terminated because of its pricing practices. 465 U.S. at 759, 765 . Monsanto, the manufacturer, contended that it had terminated Spray Rite not because of its pricing, but because of inadequate sales promotion. Id. at 757. The jury found that Monsanto's actions were taken pursuant to a conspiracy between Monsanto and the complaining distributor to set resale prices. Id. at 758. The Court of Appeals for the Seventh Circuit affirmed in substance, holding that a plaintiff can survive a motion for a directed verdict if it shows that a manufacturer terminated a price cutting distributor in response to complaints by other distributors. Spray Rite Service Corp. v. Monsanto Co., 684 F.2d 1226, 1238-39 (7th Cir. 1982). 
The Court then conducted its own economic analysis of the conspiracy, ostensibly to demonstrate its implausibility. The Court surveyed a number of prominent authorities on predatory pricing schemes and stated that such actions are "rarely tried" and even more rarely successful. ${ }^{48}$ Among the reasons suggested by the Court were the unwillingness of all conspirators to sustain long-term losses, their inability to allocate any long-term gains, and the intended victim's ability to sell at the real market price should there be too few goods to satisfy market demand. ${ }^{49}$

Applying the latter principle to the historical facts of the alleged conspiracy, the court then noted that "two decades after the conspiracy is alleged to have been commenced, [defendants] appear far from achieving the goal. The two largest shares of the [American] market are held by RCA and Zenith, and not by any of the defendants." 30 Further, the court noted that the sustained below cost pricing by the alleged conspirators caused them

(Footnote continued from previous page)

The Supreme Court affirmed, but rejected the Seventh Circuit's statement concerning the standard of proof required to submit a case to the jury in conspiracy cases. 465 U.S. at 759,764 . In its stead, the Court promulgated the more general rule that a plaintiff must present evidence that "tends to exclude the possibility of independent action." Id. at 764. Under this standard, a plaintiff must show "direct or circumstantial evidence that reasonably tend to prove that the manufacturers and others had a conscious commitment to a common scheme designed to achieve an unlawful objective." Id. at 764. The Court found that the communications between Monsanto and its distributors, coupled with a newsletter outlining a price maintenance scheme among distributors created a cognizable inference of conspiracy. Id. at 765-68.

For extensive discussion concerning the propriety of the Monsanto rule, see generally Hay, "Vertical Restraints After Monsanto," 70 CoRNELL L. REV. 418-445 (1985); Floyd, "Vertical Antitrust Conspiracies After Monsanto and Russell Stover," U. KAN. L. Rev. 269-304 (1985); Calvani and Berg, "Resale Price Maintenance After Monsanto; A Doctrine Still at War With Itself," 84 DuKe L.J. 1163-1204 (1984).

48 Matsushita Electric Industrial Co., Ltd. v. Zenith Radio Corp., 106 S. Ct. 1348, 1357-58 (1986).

$49 \quad$ Id. at 1358.

so Id. 
to accrue significant losses. ${ }^{51}$ To recover these losses, the court stated, the cartel would have to remain in force for several years after the hoped for extinguishment of the competition. ${ }^{52}$

Additionally, the court stated that the great uncertainty that would accompany a conspiracy under these circumstances eliminated any possible motive that the conspirators could have. ${ }^{53}$ Further, the court found that defendants, as presumably rational business persons, had every incentive not to engage in the conduct with which they were charged. The Court chastised the appellate panel for ignoring the lack of motive and for focusing instead on the existence of supposed direct evidence of concert of action. ${ }^{54}$ This misplaced focus, the court noted, led the Third Circuit to its erroneous conclusion that a material fact question remained concerning the existence of a conspiracy. The court then cited First Nat'l Bank v. Cities Service Corp..$^{\text {s5 }}$ for the proposition that lack of motive bears on the range of permissible conclusions that might be drawn from ambiguous evidence. ${ }^{56}$ If defendants had no rational motive to conspire, the court concluded, then the conduct "does not give rise to an inference of conspiracy." Accordingly, the Court reinstated the trial court's grant of summary judgment for defendants.

\footnotetext{
$51 \quad I d$. at 1359.

s2 Id.

53 Id. at $1360-1361$.

54 Id. at 1361. According to the Court, the "direct evidence" on which the appellate court relied was evidence of other combinations, not of a predatory pricing conspiracy. The Court stated that the "direct evidence" pointed only to a conspiracy in Japan to raise prices. This conspiracy to raise profits in one market, the Court noted, did not evidence a conspiracy to sustain losses in another. $106 \mathrm{~S}$. Ct. at 1361.
}

55391 U.S. 253 (1967).

56 Matsushita, 106 S. Ct. at 1361.

57 Id. 
The Supreme Court's affirmance of the lower court's summary judgment order evidences a misapplication of existing conspiracy and summary judgment law. By requiring conspiracy plaintiffs to demonstrate the economic plausibility of the substantive goal of an alleged conspiracy, the Court has created a significant new barrier to plaintiffs seeking jury review; the fact that it may be irrational in theory for a particular seller to engage in long-term predatory pricing cannot contradict the record evidence that numerous sellers, in fact, have engaged in such conduct. Evidence of such consciously parallel "irrational" below-cost selling by multiple sellers constitutes positive evidence of a conspiracy, moreover, because such conduct is contrary to the economic self-interest of each defendant, were it acting unilaterally, as will be discussed below. In any event, Matsushita plaintiffs apparently must argue the merits of a designated set of economic theorems: in particular, they must rely on economic assumptions acceptable to laissez-faire economists. ${ }^{58}$ In so holding, the Court has deprived the factfinder of the opportunity to weigh competing inferences to be drawn from each party's experts. Moreover, the Court has repudiated generations of case law addressing summary judgment standards in antitrust cases.

\section{Traditional standards for granting summary judgment and their application to Matsushita}

As the Matsushita court itself notes, Rule 56 of the Federal Rules of Civil Procedure permits the grant of summary judgment if the documents on file "show there is no genuine issue as to any material fact and the moving party is entitled to relief

58 The Court referred to the writings of several economists in holding that the alleged conspiracy was economically implausible. Among those cited were former professors, now Judges Bork, Easterbrook and Posner. $106 \mathrm{~S}$. Ct. at 1357-58.

It is not contended that an evaluation of evidence based on these sources is inappropriate. Rather, it is argued that the Court's failure to relay information gleaned from these sources to a jury is contrary to the settled rule that competing theories are to be submitted to a jury. 
as a matter of law." "59 Further, summary judgment should not be granted if there is the "slightest doubt" about material facts; ${ }^{60}$ the burden of demonstrating the absence of a material factual dispute rests on the moving party. ${ }^{61}$ Finally, summary judgment is generally not appropriate if the resolution of a material issue of fact turns on the credibility of witnesses. ${ }^{62}$

While briefly referencing these settled rules, the Court did not discuss Poller v. Columbia Broadcasting System, Inc. ${ }^{63}$ the seminal decision involving antitrust summary judgment. In Poller, the Court noted that "summary procedures should be used sparingly in complex antitrust cases where motive and intent play leading roles and the proof is largely in the hands of the alleged conspirators." ${ }_{44}^{4}$ Poller has never been overruled, requiring courts to pay heed to its commands. ${ }^{65}$ Moreover, in Norfolk Monument Co.

59 Fed. R. Civ. P. 56(c). See Louis, "Federal Summary Judgment Doctrine: A Critical Analysis," 83 YALE L.J. 745 (1974); Asbill \& Snell, "Summary Judgment Under the Federal Rules-When an Issue of Fact Is Presented," 51 Mich. L. REv. 1143 (1953); Bauman, "A Rationale of Summary Judgment," 33 IND. L.J. 467 (1958).

60 Adickes v. S. H. Kress \& Co., 398 U.S. 144 (1970).

61 See, e.g., Tomalewski v. State Farm Life Ins. Co., 494 F.2d 882, 884 (3d Cir. 1974); Devet Corp. v. Houdaille Indus., Inc., 382 F.2d 17, 21 (7th Cir. 1967); Zenith Radio Corp. v. Matsushita Electric Indus. Co., 513 F. Supp. 1100, 1139 (E.D. Pa. 1981).

62 See, e.g., Poller v. Columbia Broadcasting Sys., Inc., 368 U.S. 464, 473 (1962); Remak v. Quinn, 611 F.2d 36 (3d Cir. 1979).

$63 \quad 368$ U.S. 464 (1962).

64 Id. at 473. Moreover, federal courts are generally reluctant to grant summary judgment where motive and intent are at issue. See Cross v. United States, 336 F.2d 431 (2d Cir. 1964); Bragen v. Hudson County News Co., 278 F.2d 615, 618 (2d Cir. 1962).

65 As the district court in Matsushita noted, however, an argument can be made that the Poller standard has been dulled in recent years. See Zenith Radio Corp. v. Matsushita Electric Indus. Co., 513 F. Supp. 1100, 1140-1142 (E.D. Pa. 1981). The Poller rule has been criticized as 
Inc. v. Woodlawn Memorial Gardens, ${ }^{66}$ the Court reaffirmed its caution in granting summary judgment in conspiracy cases. In Norfolk, the Court stated that summary disposition is inappropriate when an alleged conspiracy has not been conclusively disproved by pretrial discovery. ${ }^{67}$ This language suggests that the summary judgment movant still shoulders a heavy burden, and that a movant must conclusively rebut all of a plaintiff's inferences suggesting a conspiracy. ${ }^{68}$

The Matsushita court ignored the Poller and Norfolk Monument decisions, focusing instead on First National Bank of Arizona v. Cities Service Co., ${ }^{69}$ a case decided after Poller, but before Norfolk Monument. In Cities, the Court affirmed a grant of summary judgment on a conspiracy claim. The Cities court did not, however, purport to overrule Poller, nor did the Cities panel attempt to modify the Poller language. Rather, the Cities court distinguished Poller by examining what it considered to be the basic question in each case-the motive behind the respective defendant's failure to do business with plaintiffs. ${ }^{70}$ In Poller, the

\footnotetext{
"an unwarranted gloss on the genuine issue requirement." Report of the National Commission for the Review of Antitrust Laws and Procedures, reprinted in 80 F.R.D. 509, 566-67 (1979). Moreover, numerous courts have granted or upheld the grant of summary judgment since the Poller case in 1962. See, e.g., Beal v. Lindsay, 468 F.2d 287, 291 (2d Cir. 1972); Dressler v. MV Sandpiper, 331 F.2d 130, 132-34 (2d Cir. 1964); Midwest Paper Prod. Co. v. Continental Group, Inc., 596 F.2d 573 (3d Cir. 1979).

Despite the frequency with which lower courts have granted summary judgment in antitrust conspiracy cases, the Supreme Court effectively adhered to the Poller standard before the Monsanto and Matsushita decisions. See Norfolk Monument Co., Inc. v. Woodlawn Memorial Gardens, 394 U.S. 700 (1969).
}

66394 U.S. 700 (1969).

67 Id. at 704.

68 See Rogers, "Summary Judgment in Antitrust Conspiracy Litigation," 10 Loy. U. CHI. L.J. 667 (1979).

69391 U.S. 253 (1968).

$70 \quad$ Id. at 285. 
Cities court noted, plaintiffs and defendants were competitors, permitting the plaintiff to plausibly argue that defendants had a motive to conspire to drive him out of business. By contrast, the parties in Cities had no competitive relationship and had motives to act unilaterally in a parallel fashion, rendering plaintiff's

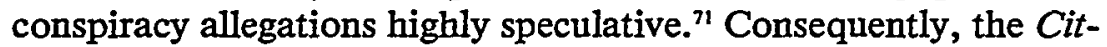
ies panel granted defendant's motion for summary judgment.

Matsushita's reliance on Cities was thus misplaced. The Cities defendant had no demonstrable motive to conspire. Conversely, in Matsushita the parties were competitors, giving defendants a joint reason to combine with others to drive plaintiff from the market. Accordingly, the Matsushita court should have applied the Poller/Norfolk analysis, the standard that remains the rule for cases involving an alleged conspiracy against a potential competitor. ${ }^{2}$

71 Id. at 285-86.

72 Two Supreme Court cases since Norfolk have affirmed Poller's rigorous summary judgment standards, albeit in divergent contexts. See Adickes v. S. H. Kress \& Co., 398 U.S. 144 (1970); Hospital Bldg. Co. v. Trustees of Rex Hosp., 425 U.S. 738, 746 (1976).

Commentators have, however, suggested that Cities constitutes a slight retreat from the Poller standard of conclusively rebutting a plaintiff's inference of conspiracy on a summary judgment motion. These observers note that the existence of a conspiracy in Cities could have been inferred from the evidence. Consequently, it can be argued that the Cities grant of summary judgment relieves a movant of the Poller burden. See Note, "First National Bank v. Cities Service Co.," 10 B.C. IND. \& CoM. L. Rev. 196, 204 (1968); Rogers, "Summary Judgment in Antitrust Conspiracy Litigation," 10 Loy. U.L. Rev. 667 (1979).

Nevertheless, as noted, the Court in Norfolk Monument Co., Inc. $v$. Woodlawn Memorial Gardens, which followed Cities, reaffirmed the Poller standard. Moreover, the Matsushita court misapplied the Cities rationale. While the Cities defendant may not have disproved all of plaintiff's inferences, the Matsushita defendants disproved none of plaintiffs' theories. Instead, the Court merely accepted defendant's bold assertions that the alleged conspiracy was economically implausible. Rather than permit a jury to weigh the contradictory testimony of each party's experts, the Court selected the theories to be applied. 
Additionally, the Matsushita decision inexplicably applied the already questionable doctrine announced in Monsanto $^{73}$ concerning the quantum of evidence required to survive a summary judgment motion in a vertical price fixing conspiracy context. In Monsanto, the Court held that a manufacturer's termination of a price cutting distributor in response to a complaint from a nonterminated distributor is not enough, standing alone, to create a jury question. ${ }^{74}$ From these facts, the Monsanto panel announced that a plaintiff alleging anticompetitive concert of action must present evidence "tending to exclude the possibility" that the alleged conspirators were acting independently in order to survive a motion for summary judgment. ${ }^{75}$

While creating a new burden for plaintiffs alleging a vertical conspiracy, the Monsanto decision is inapplicable to horizontal price fixing cases like Matsushita. The Monsanto opinion contains no expressed or implied language concerning the kind or quantity of evidence required to withstand defendant's motion for summary judgment ${ }^{76}$ in a horizontal context. Rather, as the Matsushita dissenters suggest, Monsanto simply held that presentation of a particular type of evidence in a dealer/distributor conspiracy situation is not enough to send a case to a jury. ${ }^{.7}$

\footnotetext{
73465 U.S. 752 (1984).

74 Id.

75 See note 47 and accompanying text. The Court did not address the conflict between its new standard and the "preponderance of the evidence" test traditionally used in civil cases.

76 The Monsanto Court discussed the issue only in terms of vertical conspiracies. In fact, the Court granted certiorari for the express purpose of resolving a conflict among the circuits concerning the evidence that an antitrust plaintiff must present to survive a directed verdict in a manufacturer-distributor context. 465 U.S. at 759. Moreover, each case cited by the Monsanto Court as creating the conflict dealt with dealer terminations. $I d$. at $759, \mathrm{n} .5$.
}

77 Matsushita Electric Indus. Co. v. Zenith Radio Corp., 106 S. Ct. 1348,1363 (1986). 
Finally, as a peripheral matter, the Matsushita Court summarily dispensed with plaintiff's price fixing evidence, yet did not review plaintiff's claim under the Antidumping Act of $1916 .^{78}$ The appellate court had, however, examined the dumping issue and concluded that sufficient evidence of dumping existed to preclude summary judgment. ${ }^{79}$ More importantly, the appellate panel concluded that evidence supporting plaintiff's dumping claims also created a fact question concerning defendant's alleged price fixing conspiracy ${ }^{80}$ Despite the lower court's explicit affirmation of plaintiff's conspiracy theory using plaintiff's dumping evidence, the Supreme Court allowed the appellate ruling on the dumping issue to stand. ${ }^{81}$ The Court's inaction suggests the paradoxical conclusion that defendant's alleged conspiracy was economically implausible if labeled price fixing, but commercially sensible and thus cognizable if labeled dumping.

IV. The development of the traditional evidentiary standard for criminal conspiracies

Precedent relating to conspiracy law, generally, and antitrust conspiracy law, specifically, does not support the Supreme Court's creation of an exceptional evidentiary standard for civil antitrust cases. A brief review of the developments of the Supreme Court's evidentiary standards in general criminal conspiracy cases and antitrust conspiracy cases will reveal this fact.

One of the most powerful tools used in prosecution of conspiracy cases has been the use of jury inferences in the absence

78 The Court declined to review plaintiff's dumping claim because the allegations were not mentioned in the questions presented segment of defendant's writ of certiorari, nor were they independently argued by the parties. $106 \mathrm{~S}$. Ct. at 1352, n. 3.

79 In re Japanese Electronic Products Antitrust Litigation, 723 F.2d 319 (3d Cir. 1983).

80723 F.2d at 328.

81 Matsushita Electric Indus. Co. v. Zenith Radio Corp., $106 \mathrm{~S}$. Ct. 1348, 1352, n. 3. 
of direct evidence. In Glasser $v$. United States, ${ }^{82}$ the Court for the first time discussed the use of jury inferences to find the existence of a conspiratorial agreement. The Court found that " [p]articipation in a criminal conspiracy need not be proved by direct evidence; a common purpose and plan may be inferred from a development and collection of circumstances." ${ }^{83}$ Repeatedly, the lower courts have affirmed this principle. ${ }^{84}$ The rationale behind such a rule is sound. Conspiracy is by its nature a clandestine activity; it is not necessary for the parties to have direct contact with one another or communicate verbally their intention to agree. ${ }^{85}$ It is, therefore, unlikely that the aggrieved party can prove existence by use of direct evidence, and thus the jury must be allowed to infer such existence. ${ }^{86}$ For these reasons, circumstantial evidence plays a key role in conspiracy cases because of its relevance.

In Holland $v$. United States, ${ }^{87}$ the Court reinforced its position that circumstantial evidence may be relied upon as the basis for finding the existence of criminality. The Court specifically rejected the rule that where the proponent's evidence is circumstantial, it must be such as to exclude every reasonable hypothesis

82315 U.S. 60 (1942) (prosecution for conspiracy to defraud the United States).

83 Id. at 80.

84 See United States v. Carter, 760 F.2d 1568 (11th Cir. 1985) (participation in a conspiracy need not be proved by direct evidence, but may be inferred from actions of the accused or by circumstantial evidence of a scheme); United States v. Perkins, 748 F.2d 1519 (11th Cir. 1984); United States v. Caudle, 758 F.2d 994 (4th Cir. 1985); United States v. Paradis, 802 F.2d 553 (1st Cir. 1986); United States v. Troutman, 814 F.2d 1428 (10th Cir. 1987); United States v. Tortillo, 759 F.2d 998 (2d Cir. 1985); United States v. Cardano-Alvarado, 806 F.2d 269 (5th Cir. 1986).

85 P. Marcus, "Conspiracy: The Criminal Agreement in Theory and in Practice," 65 Georgetown L. Jour. 951-52 (1977).

86 Id.

87348 U.S. 121 (1954). (Defendants were convicted of wilfully attempting to defraud the federal government and evade income taxes.) 
other than guilt. ${ }^{88}$ It reasoned that circumstantial and testimonial evidence are intrinsically the same in the sense that in some cases each may point to the incorrect result. ${ }^{89}$ But when either type of evidence is used the court can require no more than that the factfinder weigh the probabilities and convince itself beyond a reasonable doubt. ${ }^{\circ 0}$

Modern conspiracy cases adopt the rule in Holland. ${ }^{91}$ To determine the existence of a conspiracy a jury must weigh the probabilities that the defendant's actions were independent against the probabilities that defendant's acts were interdependent. The plaintiffs are not required to offer proof that rejects every reasonable hypothesis that a conspiracy does not exist.

The evidentiary standards of conspiracy that grew out of both $\S 1$ and $\S 2$ actions of the Sherman Act acquiesced with the general principles set forth in Glasser and Holland. In Interstate Circuit, Inc. v. United States, ${ }^{22}$ the Supreme Court implicitly acknowledged that in antitrust conspiracy cases, a court should permit a broad latitude of inferences based on circumstantial evidence. Then in American Tobacco Co. $v$. United States, ${ }^{93}$ the Court more fully explored the role of circumstantial evidence in proving conspiracy in Sherman Act cases. The Court stated:

No formal agreement is necessary to constitute an unlawful conspiracy . . . . The essential combination or conspiracy in violation of the Sherman Act may be found in a course of dealings or other circumstances as well as in the exchange of words. Where the

\footnotetext{
88 Id. at $139-40$.

89 Id.

90 Id. at 140.

91 See United States v. Basey, 816 F.2d 980 (1987); United States v. Rodriguez, 808 F.2d 1284 (1985); United States v. Shehane, 517 F.2d 1113,1127 (8th Cir. 1974) (it is not necessary that the evidence exclude every reasonable hypothesis, but simply that the jury is convinced beyond a reasonable doubt).
}

92306 U.S. 208 (1939). 
circumstances are such as to warrant a jury finding that the conspirators had unity of purpose or a common design and understanding or a meeting of minds in unlawful arrangement, the conclusion that a conspiracy is established is justified. ${ }^{94}$

Thus, in American Tobacco the Court recognized the necessity of circumstantial evidence in antitrust conspiracy actions as it had done in general conspiracy cases in Glasser a few years earlier.

The American Tobacco decision, in dicta, implicitly outlined a rough test to determine the validity of a jury inference of an unlawful agreement in a Sherman Act case. First, the Court identified consciously parallel conduct on the part of all the individual defendants. ${ }^{95}$ Second, the Court emphasized that several of these parallel acts had no economic justification for the defendants. For example, the Court found that although the cost of tobacco to each tobacco distributor was at its lowest level in 25 years, one of the defendants raised the price of its leading cigarette brand. The same day, two of the other defendants also raised the price of their primary brands. The Court went on to list several other economically unexplainable acts committed by the defendants..$^{96}$ Although the officials of the defendant companies gave several alternative reasons for the move, the Court impliedly accepted the jury's inference of conspiracy.

One commentator refers to the American Tobacco test as the "plus-factors approach" in that it demands proof of conscious

94 Id. at 809-10.

95 Id. at 798-808. The Court outlined the structure of the concerted oligopoly that had formed after the breakup of the American Tobacco Trust in 1911. This summary included analysis of parallel activity in the purchase as well as the distribution and sale of tobacco between nine of the largest tobacco companies in the industry. The Court's analysis concentrated on the top three companies: American Tobacco, Liggett and Reynolds. Parallel purchasing and parallel distribution and sales activities were the main actions highlighted to illustrate the parallel conduct.

96 Id. at 800-01 (purchasing), 804-07 (distribution and sale). 
parallel activity plus something more. 97 That "something more" is usually proof of conduct contrary to the company's economic self-interest or proof of economic motivation to collude. In United States $v$. Paramount Pictures, Inc.,$^{98}$ the Court affirmed a jury inference of conspiracy based on parallel activity and circumstantial proof of activity which was not in the best economic interest of the defendants. The record revealed that several movie distributors entered into agreements setting the minimum price of first run movies. Then, the defendants based their decision as to whether to sell to exhibitors (moviehouses) not on the basis of competitive factors such as appointments, size, or location but rather upon whether the exhibitor was party to the minimum price agreement. ${ }^{99}$

In 1954, Theatre Enterprise, Inc. v. Paramount Film Distr. Corp. ${ }^{100}$ the Court reemphasized the need to prove not only conscious parallelism in antitrust conspiracy cases but to also show added factors. The Court stated that while circumstantial evidence of consciously parallel behavior has made heavy inroads into traditional attitudes toward conspiracy, "conscious parallelism has not read conspiracy out of the Sherman Act entirely. ${ }^{101}$ If one carefully reads the dicta in American Tobacco, the Theatre Enterprise warning appears to be a reaffirmation that additional factors that point towards collusion must exist to allow a reasonable jury inference of conspiracy.

97 Marks, "Can Conspiracy Theory Solve the 'Oligopoly Problem,' " 45 MARY. L. Rev. 387, 404 (1986) (comparing the judicial method of proving conspiracy in an oligopoly setting and various other methods such as Judge Posner's approach); see also SchwarTz, FLYNN, AND First, ANTItrust 447 (6th ed. 1983).

$\begin{array}{ll}98 & 334 \text { U.S. } 131 \text { (1948). } \\ 99 & \text { Id. at } 146 . \\ 100 & 346 \text { U.S. } 537 . \\ 101 & I d . \text { at } 540-46 .\end{array}$


Continental Ore Co. v. Union Carbide \& Carbon Corp. ${ }^{102}$ added yet another guideline for the proper evidentiary standards in antitrust conspiracy cases. It warned against fragmenting or compartmentalizing the evidence in an antitrust conspiracy case. ${ }^{103}$ In order for legitimate inferences about the ultimate facts at issue to be drawn, all of the admissible evidence, direct and circumstantial must be examined. ${ }^{104}$

The recognition that a criminal prosecutor should not be required to introduce evidence excluding all hypotheses of innocence is of relatively recent origin. Representative of contrary early cases is Pevely Dairy Co. v. United States. ${ }^{105}$ In that case, two dairy companies allegedly conspired to fix milk prices. The Eighth Circuit there held that a government prosecutor relying on circumstantial evidence must not only prove guilt beyond a reasonable doubt, but must also show that "all facts are inconsistent with any other rational conclusion than that of guilt of the defendants." 106

$$
\begin{aligned}
& 102370 \text { U.S. } 690(1962) . \\
& 103 \quad I d . \text { at } 699 .
\end{aligned}
$$

104 Id. Thus, the Court's approach is not only inconsistent with the standard in criminal antitrust actions, but is also at odds with its approach in other types of litigation. In employment discrimination cases, for example, the Court has held that a jury inference of discrimination under Title VII is established by proof that a plaintiff is qualified for the position, that the plaintiff was rejected, and that the employer continues to seek applicants with like credentials. See, e.g., Texas Department of Community Affairs v. Burdine, 450 U.S. 248, 254 and n. 6 (1981); McDonnell Douglas Corp. v. Green, 411 U.S. 792, 802 (1973). Such evidence does not exclude the possibility that an employer rejected the applicant for nondiscriminatory reasons. Nevertheless, the Court has held that this evidence is not only sufficient for a jury inference of discrimination, but also that it compels the inference unless the defendant presents a nondiscrimnatory motive for its action. Burdine, 450 U.S. at 254-56 and nn. 7-8.

105178 F.2d 363 (8th Cir. 1949).

$106 \quad I d$. at 367. 
Current case law, by contrast, as noted above, rejects the hypothesis of innocence test in favor of the beyond a reasonable doubt standard. In United States $v$. Moya ${ }^{107}$ the Seventh Circuit identified the reasonable doubt test as the sole standard for reviewing the sufficiency of the evidence in criminal cases. ${ }^{108}$ In reaching this conclusion, the Court drew a clear distinction between the two standards. The reasonable doubt test, the Court noted, requires a reviewing court to examine whether a factfinder confronted with conflicting hypotheses considered the evidence according to the prosecution's inferences. ${ }^{109}$ The hypothesis of innocence test, by contrast, requires an appellate court to decide whether a factfinder could reasonably conclude that the evidence is inconsistent with the defendant's hypothesis. ${ }^{10}$

Further, the Fourth Circuit recently affirmed the reasonable doubt standard in a criminal antitrust conspiracy case. In United States v. W. F. Brinkley \& Sons Const. Co., ${ }^{11}$ the Court upheld jury instructions requiring the prosecution to demonstrate that no reasonable doubt existed concerning the defendants' participation in a bid-rigging arrangement. Despite the presence of plausible evidence indicating that the defendants might have acted unilater-

107721 F.2d 606 (7th Cir. 1983). See also Moore v. Boating Indus. Assoc., 754 F.2d 698, 712 at n. 22 (7th Cir. 1985); United States v. Weed, 689 F.2d 752 (7th Cir. 1982); United States v. Bell, 678 F.2d 547 (5th Cir. 1982), aff'd on other grounds, __ U.S. _, 103 S. Ct. 2398 (1983); compare Jackson v. Virginia, 443 U.S. 307, 319 ("court should determine whether, after viewing the evidence in the light most favorable to the prosecution, any rational trier of fact could have found the essential elements of the crime beyond a reasonable doubt'"). See generally "United States $v$. Bell and the Directed Verdict in Criminal Cases: The Death of the Two Hypotheses Rule," 35 Mercer L. REv. 1209-1226 (1984).

108 United States v. Moya, 721 F.2d 606, 610 (7th Cir. 1983).

109 Id.

$110 I d$.

111783 F.2d 1157 (4th Cir. 1986). 
ally, ${ }^{112}$ the Court affirmed the appellant's conviction. That the Court upheld the reasonable doubt standard under these circumstances evidences a firm resistance to a return to a hypothesis of innocence standard in criminal antitrust actions.

It is therefore apparent that civil antitrust plaintiffs and criminal prosecutors face distinct tasks in bringing antitrust suits; the criminal complainant clearly shoulders a lesser burden. In the event that the new Matsushita rule is adopted for criminal antitrust suits, however, the prosecutor's job would be made significantly more difficult. Adherence to the Matsushita standard in criminal cases would mandate an effective return to the hypothesis of innocence test for criminal defendants which, as noted, the courts have explicitly rejected. Under this standard, a criminal defendant would be entitled to a verdict merely by creating an alternative hypothesis for his conduct.

Conversely, if the Matsushita standard is not applied to criminal antitrust cases, then an anomalous gap in standards of proof between civil and criminal antitrust cases obtains. The Matsushita requirement that a plaintiff present evidence tending to exclude the possibility of a conspiracy creates a nearly insurmountable barrier to jury review for civil complainants. By contrast, a criminal prosecutor can prove his case using a reasonable doubt standard. Thus, it becomes more difficult for a civil plaintiff to reach a jury than for a prosecutor to persuade a jury.

Moreover, if Matsushita is confinled to civil cases, reasonable observers could suggest that ideology plays a role in the Supreme Court's decision making process. Imposing a stiffer burden on the civil antitrust plaintiffs in Matsushita than on criminal prose-

112 In Brinkley, two contractors serving as immunized witnesses for the prosecution testified that they had been unable to obtain certain cost data necessary to submit a competitive bid on a construction project. Rather than anger employees who had worked hard to put the rest of the bid package together, the contractors decided to submit a noncompetitive bid. Subsequently, they contacted defendant, who supplied them with a "safe" amount to bid. The Court rejected defendant's contention that the contractors' action constituted unilateral behavior because they decided to submit a noncompetitive bid prior to their discussions with defendant. 783 F.2d at 1159. 
cutors gives rise to the inference that this Court prefers the Justice Department over so-called private attorneys general. If this is true, the only consistency in antitrust cases will be that civil defendants will virtually always prevail unless also facing a criminal indictment.

V. The appropriateness of economic analysis and logic in adjudicating Sherman Act conspiracy allegations

The Matsushita Court's pronouncements were effectively made by a panel examining a summary judgment record bereft of direct evidence of conspiracy. While the appellate court found plaintiffs' evidence probative of a conspiracy to fix minimum prices, the Supreme Court characterized the same evidence as irrelevant. ${ }^{113}$ Plaintiffs had not, according to the Court, presented direct evidence of a predatory pricing scheme. Rather, plaintiffs had produced facts evidencing collateral conspiracies permitted under United States law. ${ }^{114}$

Despite its disagreement with the Court of Appeals concerning the existence of direct evidence of a minimum price-fixing conspiracy, the Court could have profitably, examined defendant's behavior by employing elements of traditional "conscious parallelism" doctrine. This doctrine is often applied where no direct evidence of conspiracy exists. ${ }^{11}$ An analysis of plaintiffs'

113 Matsushita Electric Indus. Co. v. Zenith Radio Corp., 106 S. Ct. 1348, 1361 (1986).

114 The Court stated that the "direct evidence" on which the Court of Appeals relied was merely evidence of a conspiracy to fix high prices in Japan. This conspiracy, the Court noted, did not support plaintiff's allegation of a domestic price fixing conspiracy, since "a conspiracy to increase profits in one market does not tend to show a conspiracy to sustain losses in another." $106 \mathrm{~S}$. Ct. at 1361. The Court also characterized evidence that defendants had agreed to a horizontal territorial allocation as irrelevant, since "the natural effect would be to raise market prices rather than reduce them." Id.

115 See, e.g., Interstate Circuit, Inc. v. United States, 306 U.S. 208 (1939); Bogosian v. Gulf Oil Corp., 561 F.2d 434 (3d Cir. 1977). See 
evidence under the conscious parallelism principle necessitates, however, a brief review of its requirements.

\section{A. Conscious parallelism as circumstantial evidence of conspiracy}

Conscious parallelism generally refers to the common practice among firms in a concentrated industry of conducting their business in a uniform manner, aware that their counterparts are pursuing the same course of action. ${ }^{116}$ Proof of conscious parallelism does not, however, constitute concerted action in violation of the Sherman Act. Instead, courts have required additional evidence of conspiracy ("plus factors') to find antitrust liability. ${ }^{117}$ The most frequently employed plus factor is proof that the parallel behavior was contrary to each firm's economic self interest. ${ }^{118}$

Courts have, however, differed concerning the precise meaning of "against economic self interest." "119 Literal application of

generally Turner, "The Definition of Agreement Under the Sherman Act: Conscious Parallelism and Refusals to Deal," 75 HARv. L. Rev. 655 (1962).

116 Note, "Conscious Parallelism and the Sherman Act: An Analysis and a Proposal," 30 VAND. L. Rev. 1227, 1228 (1977). See also Blechman, "Conscious Parallelism, Signalling and Facilitating Devices: The Problem of Tacit Collusion Under the Antitrust Laws," 24 N.Y.L. ScH. L. Rev. 881 (1979). For economic analyses of conscious parallelism, see P. Samulison, Economics, chs. 2-4, 20-26 (9th ed. 1973) and R. Posner, Antitrust Law: An Economic Perspective (1976).

117 "Plus factors are independent items of evidence that, when coupled with evidence of conscious parallelism, tend to support a finding of collusive agreement." Montana v. Super America, 557 F. Supp. 298, 302 (D. Mont. 1983).

118 Bogosian v. Gulf Oil Corp., 561 F.2d 434, 444 (3d Cir. 1977) (quoting Venzie Corp. v. United States Mineral Prod. Co., 521 F.2d 1309, 1314 (3d Cir. 1975)), cert. denied, 434 U.S. 1086 (1978).

119 See, e.g., Amey v. Gulf Abstract \& Title, Inc., 758 F.2d 1486, 1503 (11th Cir. 1985); Pan Islamic Trade Corp. v. Exxon Corp., 632 
the test is technically impossible, since a rational profit maximizing firm will always act in its perceived self-interest. ${ }^{120}$ Further, a firm can maximize profits by entering into a price fixing agreement; an antitrust defendant could therefore always rebut a conscious parallelism allegation by arguing that any means of increasing prices, including a conspiracy to fix prices, would also advance the firm's interest by increasing profits. ${ }^{21}$ Apparently, recognizing these theoretical barriers, some circuits have modified the original economic self-interest test. These courts permit an inference of conspiracy when "the pattern of action undertaken is inconsistent with the self-interest of the individual actors, were they acting alone." ${ }^{122}$ This rule parallels cartel theory which suggests that group stabilization of prices and reduced output enables the participants to achieve a higher market price than would be possible if competitive conditions were present. ${ }^{123}$

Finally, in Venzie Corp. v. United States Mineral Products Co., ${ }^{124}$ the Third Circuit announced that a second prong should be added to the against economic self-interest test for evaluating ambiguous evidence of conspiracy. The Court held that an antitrust plaintiff must not only demonstrate acts in contradiction

F.2d 539, 359 (5th Cir. 1980); Milgram v. Loew's Inc., 192 F.2d 579, 583 (3d Cir. 1951); Independent Iron Works, Inc. v. United States Steel Corp., 322 F.2d 656, 661 (9th Cir. 1961).

120 Mansfield, Microeconomics, 141-47 (3d ed. 1979).

121 Note, "Conscious Parallelism and Price Fixing: Defining the Boundary," 52 U. CHI. L. REv. 508, 521-22 (1985).

122 Proctor v. State Farm Mut. Auto Ins. Co., 675 F.2d 308, 327 (D.C. Cir.), cert. denied, 459 U.S. 839 (1982); Admiral Theatre Corp. v. Douglas Theatre Co., 585 F.2d 877, 884 (8th Cir. 1978); Modern Home Inst. Inc. v. Hartford Accident \& Indemn. Co., 513 F.2d 102, 111 (2d Cir. 1975).

123 R. Posner \& F. Easterbrook, Antitrust: Cases, Economic Notes, and Other Materials, 1064, 1065 (cited in Note, "Conscious Parallelism and Price Fixing: Defining the Boundary," 52 U. CHI. L. REv. 508, 52122 (1985). 
of economic self-interest, but must also present a legitimate motivation for defendants to enter into an agreement. ${ }^{125}$ The addition of the motive requirement was necessary in the Court's view because in the absence of a demonstration of how it would benefit a party to conspire, the requisite inference of conspiracy does not follow from mere coincidence of conduct. ${ }^{126}$

\section{B. Application of conscious parallelism principles to Matsushita: the against economic self-interest test}

As noted, some courts permit an inference of conspiracy when the alleged conspirator's behavior is contrary to their economic self interest. ${ }^{127}$ Accepting the premise that that test contravenes elementary economic theory when applied in a minimum price-fixing contest, ${ }^{128}$ the appropriate standard becomes the related concept requiring a showing that defendants' acts would be inconsistent with their self interest were they acting alone. ${ }^{129}$ Before turning to the applicability of these principles to Matsushita, however, it is necessary to identify the evidence described by the Matsushita Court as mere inferential proof. ${ }^{130}$

125 Venzie Corp. v. United States Mineral Prod. Co., 521 F.2d at 1314 (citing First Nat'l Bank v. Cities Serv. Co., 391 U.S. 253, 287 (1968), and Delaware Valley Marine Supply Co. v. American Tobacco Co., 297 F.2d 199 (3d Cir. 1961), cert. denied, 369 U.S. 839 (1962)).

126 Venzie, 521 F.2d at 1315; First Nat'l Bank v. Cities Serv. Co., 391 U.S. 253, 282 (1968). See, Note, "Conscious Parallelism: The Business Judgment Defense in a Summary Judgment Context," 35 Hastings L.J. 115 (1983).

127 See notes 120-123 and accompanying text.

$128 I d$.

129 See notes 122-23 and accompanying text.

130 As the four dissenters note, the Court of Appeals treated much of plaintiff's proof as direct evidence of conspiracy, consequently, the 
First, the Court noted the appellate court's finding that defendants had, by formal agreements with the Japanese Ministry of International Trade and Industry (MITI) fixed minimum prices for consumer electronic products, prices that produced substantial losses for defendants. ${ }^{131}$ Second, the Court acknowledged the possible existence of the Japanese manufacturer's "Five Company" rule, whereby each manufacturer agreed to sell to only five American distributors. ${ }^{12}$ Lastly, the Court addressed the Court of Appeals' finding that a reasonable factfinder could conclude that each defendant undercut its own minimum prices by secretly offering rebate schemes to its respective customers. ${ }^{133}$ Evaluating each action, it is apparent that all would be inconsistent with the economic self-interest of any defendant acting independently. A profit maximizing businessperson would not sustain substantial losses by maintain-

case "could be distinguished from traditional conscious parallelism situations in that direct evidence of a price fixing conspiracy existed." Matsushita Electric Indus. Co. v. Zenith Radio Corp., 106 S. Ct. 1348, 1364-65 (1986) (White, J. dissenting) (citing in re Japanese Electronics Products Antitrust Litigation, 723 F.2d 238, 304-305 (3d Cir. 1983).

The majority treated plaintiff's proof as, at best, indirect evidence of concerted action. See infra notes 90-94 and accompanying text. Given the existence of even this arguably ambiguous evidence of a conspiracy, the Matsushita Court erred in failing to explicitly apply conscious parallelism principles. Had it done so, the Court could have clarified the version of the against economic self-interest test to be applied when only parallel activity is present.

131 Matsushita, 106 S. Ct. at 1353.

132

Id.

133 Id. The Court also noted that the appellate court permitted several additional inferences. According to the Court of Appeals, a reasonable factfinder could conclude that the Japanese market was characterized by oligopolistic behavior, with a small number of producers exchanging information on pricing and non-pricing practices. Further, the appellate panel permitted the inference that Japanese plant capacity exceeded the needs of the Japanese market, and that the Japanese defendants had relatively higher fixed costs than their American counterparts, requiring that the plants operate at full capacity in order to maintain a profit. $I d$. 
ing below market pricing, ${ }^{134}$ nor would she limit her activity in a nationwide market to five customers. ${ }^{135}$ Most obviously, secret rebates would be unnecessary and illogical in the absence of concerted action. Accordingly, the Court could have found an inference of conspiracy under this version of the against economic self interest test.

\section{Application of the motive test in Matsushita}

While omitting a discussion of the against economic self interest standard, the Matsushita Court did employ a motive analysis. ${ }^{136}$ The Court did not, however, properly apply the motive test. As noted, the appropriate motive inquiry concerns the extent to which defendants would generally benefit from the alleged conspiracy. Rather than resolve this question, the Court improperly confined its discussion to economic theorizing, ${ }^{137}$ resulting in its erroneous conclusion that the plaintiff had not presented enough evidence to avoid summary judgment. This distortion of the motive requirement, as noted below, contra-

134 It is noteworthy that the Matsushita majority itself affirmed that as presumably rational businesspersons, the defendants had every incentive to engage in the conduct with which they were charged, for its likely effect would be to generate losses for the petitioner with no corresponding gains. $106 \mathrm{~S}$. Ct. at 1348.

135 As the Matsushita majority notes, the Court of Appeals found that defendants created plant capacity which exceeded that which could be absorbed by the Japanese home market for consumer electronic products. Matsushita, $106 \mathrm{~S}$. Ct. at 1348 (citing In re Japanese Electronics Litigation, 723 F.2d at 238, 307 (3d Cir. 1983)). Consequently, according to the appellate court, a factfinder could reasonably infer from the existence of such excess capacity that those manufacturers had strong incentives to dispose of the excess capacity in foreign markets. Id. Moreover, since unlimited price competition in outside markets characterized by excess capacity would be likely to cause losses, it is reasonable to infer that competitors would collude to fix prices. In re Japanese Electronics Litigation, 723 F.2d 238, 307 (3d Cir. 1983).

136 Matsushita Electric Indus. Co. v. Zenith Radio Corp., $106 \mathrm{~S}$. Ct. 1345, 1356-66 (1986).

137 Id. 
venes the Court's earlier pronouncement in Cities Services $v$. First National Bank of Arizona. ${ }^{138}$ Paradoxically, the Court repeatedly cited Cities as its sole authority for its instructions that inferences of conspiracy must be supported by a subjective demonstration of the conspiracy's economic legitimacy.

In Cities, the plaintiff alleged that seven oil companies had engaged in a concerted refusal to purchase his oil. ${ }^{139}$ The conspiracy allegedly began after the Iranian government nationalized numerous properties of the Anglo Iranian Oil Company. ${ }^{140}$ Following the expropriation, plaintiffs purchased oil from the company formed by the Iranian government to take over Anglo Iranians' properties. Subsequently, six of the defendants agreed to boycott plaintiff's oil. Cities Service Company, following protracted negotiation with the plaintiff, allegedly joined the conspiracy after receiving a Kuwaiti bribe. ${ }^{141}$ In affirming the trial court's grant of summary judgment, ${ }^{142}$ the Court concluded that plaintiff had not raised a sufficient inference of conspiracy to warrant jury review. The Court found that the defendant's motives in refusing to deal with plaintiff arose not from any bribe, but from the exercise of business judgment. ${ }^{143}$

An inquiry into the type of business decision making the Court cited as justifying summary judgment is instructive. After nationalizing Anglo Iranian, the Iranian government publicly announced its intention to bring lawsuits against any purchaser of Iranian oil. ${ }^{44}$ Additionally, the other oil company defen-
138391 U.S. 253 (1968).
139 Id. at 259-61.
140 Id. at 260.
141 Id. The alleged bribe consisted of a substantial supply of oil from Kuwait at a price lower than that offered by the plaintiff.

142 Waldron v. British Petroleum Co., 38 F.R.D. 170 (S.D.N.Y. 1965).

143 First National Bank of Arizona v. Cities Service Co., 391 U.S. 253, 286-88 (1968).

144 Id. 
dants, as apparent consequences of their fear of nationalization by the governments of countries in which they possessed substantial holdings, relayed to Cities their intention to discontinue dealings with any company that bought Iranian oil. ${ }^{45}$ Consequently, the Court concluded, Cities' failure to purchase plaintiff's oil resulted not from conspiratorial behavior, but from a sensible reaction to business realities. ${ }^{146}$

Lower courts relying on Cities Services have similarly characterized the motive requirement for summary judgment movants as involving the exercise of independent business decision making. In Solinger v. A. \& M. Records, Inc., ${ }^{147}$ plaintiff record distributors alleged a territorial allocation conspiracy between defendants, with the defendant record producers allegedly conspiring to put the plaintiffs out of business. In granting defendant's motion for summary judgment, the Court noted that summary disposition is appropriate if a defendant rebuts con-

145 Id. at 278. In its brief, the plaintiff argued that Cities' participation in the alleged conspiracy was obtained by these retaliatory threats. Because the plaintiff made no reference to the theory at trial, the Court declined to review these contentions or any legal questions they raised. Id. at 280 , n. 16.

146 Id. at 286-88. The Cities decision represented an affirmation of the Sherman Act's deference to independent business judgment. The Supreme Court first sanctioned a business judgment defense in Theatre Enterprises v. Paramount Film Distributing Corp. In that case, an operator of a suburban movie theatre alleged that certain movie producers and distributors had conspired to restrict showings of first-run films to downtown theatres. While conceding that evidence of conspiracy existed, the plaintiff contended that the defendant's behavior created an inference of a conspiracy to drive the plaintiff from the first-run movie market. The defendants responded that downtown theatres simply offered several business advantages, including access to a larger audience by virtue of the availability of public transportation downtown. Accordingly, the Court granted defendant's motion for summary judgment. 346 U.S. 537, 540 (1953).

For a careful analysis of cases addressing the business judgment standard, see Note, "Conscious Parallelism: The Business Judgment Defense in a Summary Judgment Context," 35 Hastings L.J. 115 (1983). 
spiracy allegations with probative evidence showing "legitimate business reasons" for the defendant's conduct. ${ }^{148}$ Likewise, in Consolidated Farmers Mutual Ins. Co. v. Anchor Savings Association, the Court held that when the record poses a variety of nonconspiratorial motives for the defendants' acts, rooted in business judgment, the defendants are entitled to summary judgment. ${ }^{149}$

In considering the impact of Cities Services and its progeny on the rules for granting summary judgment in antitrust conspiracies cases, it is important to note the quantity as well as the character of the evidence presented by a successful movant. In Cities, the Court granted the defendant's motion when it found "overwhelming" evidence that Cities' motives arose in the exercise of business judgment rather than pursuant to a conspiracy. ${ }^{150}$ In Solinger, the defendants presented clear evidence that the supposed beneficiary of the alleged conspiracy to prevent sales to the plaintiff simply made the defendants a better

149480 F. Supp. 640 (D. Kan. 1979). In Consolidated, the plaintiffs wanted to provide hazard insurance for property securing mortgages that defendant banks originated. The plaintiffs did not, however, have the financial resources to meet the defendant's standards for property insurers, and defendants purchased insurance elsewhere. Subsequently, the plaintiffs alleged a conspiracy between the banks and the government agencies to whom the bankers sold mortgages.

In granting the defendant's motion for summary judgment, the court noted that the government agencies purchasing the bank's mortgages justifiably established an objective standard to identify acceptable hazard insurance carriers for the mortgages it purchased. Without the standards, the agency would be required to scrutinize the financial stability of the thousands of insurance companies providing hazard insurance. Because the banks wanted to sell mortgages they originated to these government agencies, they unilaterally adopted the agencies' standards. 480 F. Supp. $640,647-48$. The defendants therefore had no malicious intentions toward the plaintiffs, but instead acted pursuant to their legitimate business interests. $480 \mathrm{~F}$. Supp. at 650 .

150 First National Bank of Arizona v. Cities Service Co., 391 U.S. $253,277-284$ (1967). 
offer. ${ }^{151}$ In Consolidated, after noting that summary judgment may be granted when defendants have introduced "extensive and substantial evidence" negating a plaintiff's conspiracy theory the Court held that the defendants lawfully refused to do business with the plaintiffs out of their legitimate concerns for the plaintiffs' solvency. ${ }^{152}$

\section{Conclusion}

With its decision in Matsushita, the Supreme Court has apparently changed the standards for opposing a defendant's motion for summary judgment in a Section One conspiracy case. In extending Monsanto, the Court has made the plaintiff's task of surviving a summary judgment motion significantly more difficult. By requiring a demonstration that an alleged conspiracy makes economic sense to a trial judge, the Court has adopted a rule that no longer requires a judge to determine merely whether an issue of material fact exists, but instead invites a judge to weigh the conflicting economic theories of the parties.

Additionally, the Court's decision has created an unprincipled distinction in the standards of proof of conspiracy that civil plaintiffs and criminal prosecutors must meet. The Court's decision effectively makes it easier for a prosecutor to prove his case than for a civil plaintiff to obtain jury review.

Finally, the Court misapplied the Cities standard with regard to nature of the motive that a plaintiff must demonstrate to survive a summary judgment motion under conscious parallelism principles. Notwithstanding the Matsushita Court's conclusions, the Cities rule does not require a court to consult its favorite economists to divine the absence of a defendant's motive to conspire. Rather, Cities merely requires an inquiry into the facial realities of the business environment.

151 Solinger v. A. \& M. Records, Inc., 538 F. Supp. 402, 409 (N.D. Calif. 1982).

152 See note 149 supra and accompanying text. 
If Matsushita represented merely a choice between conflicting interpretations of the Sherman Act, its illogic could be accepted or, perhaps, legislatively overruled without alarm. But the decision reflects broader political questions about the traditional role and power of juries in our democratic system to adjudicate private property rights and the attempt by the executive branch to infect otherwise private disputes with its noninterventionist ideology, thereby transforming the judiciary from its essential nonactivist role. 